\title{
ANALISIS PENGARUH KESEJAHTERAAN KARYAWAN TERHADAP SEMANGAT KERJA KARYAWAN PADA PT. ASURANSI JIWASRAYA (PERSERO) MEDAN
}

\author{
Betniar Purba \\ Universitas Katolik Santo Thomas Medan Jl. Setia Budi No. 479F, 20132, Indonesia \\ e-mail: betniarpurba20@gmail.com
}

\begin{abstract}
The purpose of this study was to determine and analyze the influence of employee welfare on employee morale at PT. Asuransi Jiwasraya (Persero) Medan, for the development of science, especially in the field of human resource management, as a reference in conducting further research. The total sample of the study was all members of the population of 30 people. The type of data used are primary and secondary data, data analysis methods are used simple linear regression analysis. From the results of the research and discussion, the tcount is 7.767 with a significance level of 0.000 , so H1 is accepted and HO is rejected. That is, employee welfare has a significant effect on employee morale at PT. Jiwasraya Insurance (Persero) Medan, can be received at a 5 percent significance level. The simple linear regression equation obtained is $Y=0.773+0.696 \mathrm{X}$. That is, employee welfare has a positive effect on employee morale at PT. Jiwasraya Insurance (Persero) Medan. This can be seen from the regression coefficient which is positive. The value of the correlation coefficient $(R)$ is 0.826 , meaning that employee welfare has a strong relationship with employee morale at PT. Jiwasraya Insurance (Persero) Medan. The determinant coefficient value ( $R$ Square) is 0.683, meaning that employee morale can be explained by employee welfare of $68.3 \%$ while $31.7 \%$ is explained by other factors such as promotion and incentive. Suggestions given as material for consideration to the leadership of the company is to increase employee morale, the company should pay attention to the welfare of employees by providing official housing facilities and increase family benefits to employees. It is better for the company to increase employee morale by giving awards to the best performing employees, such as promotion and incentives.
\end{abstract}

Keywords: employee welfare and employee morale

\section{PENDAHULUAN}

Usaha yang dapat mempertahankan karyawannya, terutama mereka yang memiliki prestasi yang tinggi. Salah satu cara yang dapat dilakukan oleh perusahaan adalah dengan memberikan program kesejahteraan, karena seorang karyawan akan bekerja dengan sungguhsungguh apabila kebutuhannya telah terpenuhi. Program kesejahteraan meliputi pembayaran upah pada waktu tidak kerja, perlindungan ekonomi, program pelayanan karyawan dan pembayaran kompensasi yang diterapkan secara legal. Pembayaran gaji pada saat tidak bekerja karena istirahat, sakit, liburan atau cuti. Perlindungan ekonomi berbentuk asuransi pensiun, yang berfungsi untuk menjamin penghasilan karyawan sesudah pensiun. Program pelayanan karyawan berupa program rekreasi, cafetaria, perumahan, beasiswa, konseling finansial dan legal. Selain itu, juga termasuk hal-hal yang diatur dalam peraturan ketenagakerjaan. Dimana diharapkan dengan program ini dapat menumbuhkan suatu kepuasan yang tinggi dari karyawan serta akan menimbulkan semangat kerja secara optimal sehingga produktivitas kerja tercapai.

Semangat kerja karyawan merupakan keinginan dan kesungguhan karyawan dalam menyelesaikan tugas-tugas yang dibebankan oleh atasan kepadanya. Semangat kerja karyawan merupakan unsur yang sangat penting demi tercapainya tujuan sebuah organisasi. Manajemen dapat meningkatkan semangat kerja karyawan melalui pemenuhan kebutuhan bawahan, dan jika karyawan merasa kebutuhannya terpenuhi, maka akan termotivasi untuk bekerja lebih giat lagi atau dikatakan memiliki semangat kerja yang tinggi. Inilah dasar 
peneliti lebih memfokuskan penelitian ini dari pemenuhan kebutuhan sumber daya manusianya.

Berikut ini akan disajikan beberapa hasil penelitian tentang Pengaruh Kesejahteraan Karyawan terhadap Semangat Kerja Karyawan.

a. Hasil penelitian Khilmi, Dwi Nur, (2014) menyimpulkan bahwa kesejahteraan karyawan yang terdiri dari kesejahteraan langsung dan kesejahteraan tidak langsung yang diberikan perusahaan berpengaruh secara bersama sama terhadap semangat kerja karyawan. Berdasarkan uji yang dilakukan membuktikan bahwa kesejahteraan karyawan berpengaruh terhadap semangat kerja karyawan dengan hasil uji indikator dominan sebesar $94,07 \%$

b. Hasil penelitian Nasution, Siska Malisa (2010), menyimpulkan bahwa program kesejahteraan kerja berpengaruh positif terhadap semangat kerja karyawan pada PT. Pangansari Utama Medan. Hal ini berarti bahwa program kesejahteraan karyawan dapat meningkatkan semangat kerja. Program kesejahteraan karyawan yaitu kesejahteraan langsung dan kesejahteraan tidak langsung memberikan pengaruh signifikan terhadap semangat kerja karyawan. Berdasarkan nilai koefisien regresi diketahui bahwa semua variabel program kesejahteraan karyawan berpengaruh positif. Yang berarti semua variabel program kesejahteraan karyawan berpengaruh dalam meningkatkan semangat kerja. Karyawan PT. Pangansari Utama Medan.

c. Bagasworo (2007), hasil penelitiannya menemukakan bahwa terdapat pengaruh yang kuat dan signifikan antara pelaksanaan program kesejahteraan karyawan terhadap semangat kerja karyawan pada PT. Arcoma Timur di Jakarta.

d. Nur, Efi Zulaika dan Meita Dwi (2016), hasil penelitiannya menunjukkan bahwa kesejahteraan karyawan berpengaruh positif dan signifikan terhadap semangat kerja . hasil lain yang dapat disimpulkan adalah bahwa variabel motivasi bukan merupakan variabel moderasi dalam hubungan antara variabel kesejahteraan dan variabel semangat kerja.

PT. Asuransi Jiwasraya (Persero) Medan merupakan salah satu perusahaan jasa asuransi. Jasa yang ditawarkan berupa JS Link Fixed 95, JS Link Fixed 93 untuk produk unit link (menggabungkan unsur proteksi dan investasi), JS Prestasi dan JS Dana Multi Proteksi untuk asuransi pendidikan. Perusahaan ini memberikan fasilitas kesejahteraan kepada karyawan berupa pembayaran gaji saat tidak bekerja saat sakit, cuti dan libur, tunjangan keluarga, tunjangan hari raya, kendaraan dinas, pakaian dinas, rekreasi bersama, biaya pengobatan dan perawatan kesehatan. Semangat kerja karyawan dapat diukur dari prestasi kerja karyawan dilihat dari jumlah pemegang polis, baik yang baru masuk maupun klaim yang diselesaikan selama periode tertentu. Prestasi kerja karyawan pada PT. Asuransi Jiwasraya (Persero) Medan disajikan pada tabel berikut:

Tabel 1. Prestasi Kerja Karyawan PT. Asuransi Jiwasraya (Persero) Medan Tahun 2014- 2017

\begin{tabular}{|c|c|c|}
\hline Tahun & Jumlah (Polis) & Naik/turun \\
\hline 2014 & 3821 & - \\
\hline 2015 & 4407 & $15,34 \%$ \\
\hline 2016 & 4015 & $-8,89 \%$ \\
\hline 2017 & 3712 & $-7,55 \%$ \\
\hline
\end{tabular}

Sumber: PT. Asuransi Jiwasraya (Persero) Medan.

Dari tabel di atas, diketahui bahwa jumlah polis yang diselesaikan oleh karyawan PT. Asuransi Jiwasraya (Persero) Medan tahun 2014 sebanyak 3.821 polis dan tahun 2015 meningkat menjadi 4.407 polis atau naik 15,34\%. Jumlah polis asuransi tahun 2015 sebanyak 4.015 polis, dan jika dibandingkan dengan tahun 2015, maka jumlah polis yang diselesaikan karyawan mengalami penurunan sebesar 8,89\%. Jumlah polis asuransi tahun 2017 sebanyak 
3.712 polis, dan jika dibandingkan dengan tahun 2015, maka jumlah polis yang diselesaikan karyawan mengalami penurunan sebesar $7,55 \%$.

Berdasarkan tabel diatas diketahui bahwa semangat kerja karyawan PT. Asuransi Jiwasraya (Persero) Medan tahun 2016-2017 turun jika dibandingkan tahun 2015. Hal ini dapat disebabkan karena karyawan merasa kurang puas atas fasilitas kesejahteraan yang diberikan oleh perusahaan.

Apabila hal ini dibiarkan terjadi terus menerus, maka semangat kerja karyawan mengalami penurunan. Apabila hal ini dibiarkan terjadi secara terus menerus, maka tujuan perusahaan sulit tercapai. Oleh karena itu, masalah yang akan diteliti adalah Bagaimana pengaruh kesejahteraan karyawan terhadap semangat kerja karyawan pada PT. Asuransi Jiwasraya (Persero) Medan ?".

\section{TINJAUAN PUSTAKA}

\section{A. Pengertian Pemeliharaan Karyawan}

Keberhasilan suatu organisasi dalam mencapai tujuannya sangat ditentukan oleh keberadaan karyawan dalam organisasinya. Oleh karena itu, tidak salah jika pimpinan selalu berusaha menjaga dan memelihara karyawan nya agar merasa betah dan melaksanakan tugasnya dengan baik. Untuk mempertahankan karyawan tetap bekerja dan loyal kepada organisasi, perlu diperhatikan hal-hal lain yang berkaitan dengan pemenuhan kebutuhannya di luar gaji dan upah.

Menurut Sofyandi (2008:182), "pemeliharaan karyawan yaitu menjaga karyawan agar fisik dan mentalnya tetap sehat dalam menjalankan tugasnya, serta sikap atua emosinya tetap terkontrol".

Pemeliharaan karyawan bagi organisasi bertujuan untuk meningkatkan produktivitas kerja, memperkecil tingkat absensi, menumbuhkan loyalitas, mengurangi konflik serta menciptakan suasana harmonis. Bagi karyawan, pemeliharaan perlu dilakukan untuk meningkatkan kesejahteraan karyawan dan keluarganya, memberikan ketenangan, keamanan serta menjaga kesehatan karyawan.

\section{B. Pengertian dan Tujuan Kesejahteraan Karyawan}

Menurut Hasibuan (2003:185), "kesejahteraan karyawan adalah balas jasa pelengkap (material dan nonmaterial) yang diberikan berdasarkan kebijaksanaan". Menurut Mathis dan Jackson (2002:203), "kesejahteraan karyawan adalah imbalan tidak langsung yang diberikan kepada seseorang karyawan atau sekelompok karyawan sebagai bagian dari keanggotaannya di organisasi".

Berdasarkan pengertian tersebut, dapat dikatakan bahwa kesejahteraan karyawan merupakan balas jasa yang diberikan kepada karyawan selain gaji atau upah dan pemberiannya tidak dikaitkan langsung dengan prestasi kerja. Kesejahteraan yang diberikan hendaknya bermanfaat dan mendorong untuk mencapai tujuan organisasi, karyawan serta tidak melanggar peraturan pemerintah.

Menurut Hasibuan (2003:187), tujuan pemberian kesejahteraan karyawan antara lain:

a. Meningkatkan kesetiaan dan keterikatan karyawan terhadap organisasi.

b. Memberikan ketenangan dan memenuhi kebutuhan karyawan beserta keluarganya.

c. Meningkatkan gairah kerja, disiplin, dan produktivitas kerja karyawan.

d. Menurunkan tingkat absensi dan turnover karyawan.

e. Menciptakan lingkungan dan suasana kerja yang baik serta nyaman.

f. Membantu lancarnya pelaksanaan pekerjaan untuk mencapai tujuan.

g. Memelihara kesehatan dan meningkatkan kualitas karyawan.

h. Mengefektifkan pengadaan karyawan.

i. Membantu pelaksanaan program pemerintah dalam meningkatkan kualitas manusia Indonesia. 
j. Mengurangi kecelakaan dan kerusakan peralatan kerja.

k. Meningkatkan status sosial karyawan beserta kaluarganya.

\section{Jenis-jenis Kesejahteraan Karyawan}

Jenis-jenis kesejahteraan yang diberikan adalah finansial dan nonfinansial yang bersifat ekonomis, serta pemberian fasilitas dan pelayanan. Pemberian kesejahteraan perlu diprogram sebaik-baiknya, supaya bermanfaat dalam mendukung tujuan organisasi dan karyawan. Program kesejahteraan harus berasaskan keadilan dan kalayakan, berpedoman peraturan legal pemerintah dan didasarkan atas kemampuan organisasi untuk membayar. Menurut Handoko (2004:185), program kesejahteraan karyawan meliputi:

1. Pembayaran upah untuk waktu tidak bekerja. Periode waktu bilamana karyawan tidak bekerja, tetapi tetap dibayar adalah hasil time off benefits. Berbagai bentuk waktu tidak bekerja di mana karyawan tetap menerima pembayaran upah mencakup:

a. Istirahat on the job. Banyak bentuk umum "time-off benefits" dijumpai pada pekerjaan. Ini meliputi waktu istirahat, makan dan waktu membersihkan diri atau ganti pakaian. Dengan penyediaan waktu istirahat dalam pelaksanaan pekerjaan, produktivitas bisa meningkat.

b. Hari-hari sakit. Absen dari pekerjaan adalah tidak dapat dihindarkan. Dalam kenyataannya, hampir semua organisasi tetap membayar karyawan bila mereka absen, karena alasan kesehatan dengan pembatasan maksimum jumlah hari sakit per tahun. Untuk menghindari penyalahgunaan ketentuan hari sakit, banyak organisasi mengharuskan karyawan menunjukkan bukti sakit dari dokter.

c. Liburan dan cuti. Organisasi biasanya mengikuti hari libur resmi dalam memberikan liburan bagi karyawan nya. Dalam hal ini, organisasi perlu memperhatikan kecenderungan para karyawan memperpanjang hari libur dengan menambah hari sebelum atau sesudah liburan, terutama untuk hari kerja yang berada di tengah antara dua hari libur. Di samping itu, kebijaksanaan personalia sering memberikan waktu cuti selama batas waktu tertentu.

2. Perlindungan ekonomis terhadap bahaya.Bentuk perlindungan terhadap bahaya pertama yang umum diperhatikan organisasi adalah asuransi. Program asuransi ini bisa berbentuk asuransi jiwa, asuransi kesehatan dan asuransi kecelakaan. Di samping asuransi, ada beberapa benefits bukan asuransi yang dapat meningkatkan jaminan keamanan. Benefits tersebut bermaksud untuk menjamin penghasilan karyawan sebelum dan sesudah pensiun. Di antara bentuk benefits seperti ini mencakup: (1) jaminan pembayaran upah dalam jumlah tertentu selama suatu periode, (2) rencana pensiun, (3) tunjangan hari tua, (4) tunjangan pengobatan, dan (5) pembentukan koperasi yang mengelola kredit karyawan.

3. Program pelayanan karyawan. Pelayanan fasilitas adalah kegiatan yang secara normal dilakukan karyawan sendiri dalam kehidupannya sehari-hari. Dalam kenyataanya, banyak organisasi menyediakan berbagai bentuk bantuan atau pelayanan di bidang kehidupan rutin karyawan.

4. Pembayaran kompensasi yang diterapkan secara legal. Setiap organisasi diwajibkan memberikan perlindungan kepada karyawan terhadap bahaya yang mengancam kehidupannya.

\section{Semangat Kerja Karyawan}

Pada hakekatnya, semangat kerja merupakan perwujudan dari moral yang tinggi. Moral yang tinggi berarti memiliki semangat kerja. Menurut Nitisemito (2000:182), "semangat kerja adalah melakukan pekerjaan secara lebih giat". Menurut Saydam (2005:443), "semangat kerja adalah melakukan pekerjaan dengan semangat dan penuh dengan ketulusan dan kegembiraan. 
Menurut Anoraga (2000:81), “cara meningkatkan semangat kerja karyawan yaitu: gaji yang cukup, harga diri yang mendapat perhatian, menempatkan karyawan pada posisi yang tepat, memberikan kesempatan untuk maju dan perasaan aman menghadapi masa depan".

Seseorang bekerja dalam suatu perusahaan bertujuan untuk memenuhi kebutuhan dan keinginannya. Gaji merupakan balas jasa yang diterima seseorang atas pengorbanan yang diberikannya kepada organisasi. Karyawan mengharapkan bahwa organisasi memberikan upah yang layak sesuai peraturan yang berlaku dan kebutuhan karyawan.

Untuk melihat seberapa besar semangat kerja karyawan terhadap pekerjaannya dapat diukur dari:

1. Prestasi kerja. Menurut Mathis dan Jackson (2002:81), “prestasi kerja merupakan seberapa baik karyawan mengerjakan pekerjaan mereka ketika dibandingkan dengan satu set standar dan kemudian mengkomunikasikan informasi tersebut". Sedangkan Hariandja (2002:195), menyatakan "prestasi kerja merupakan hasil kerja yang dihasilkan oleh pegawai atau perilaku nyata yang ditampilkan sesuai dengan peranannya dalam organisasi".

2. Disiplin kerja. Disiplin dapat diartikan sebagai suatù sikap, tingkah laku dan perbuatan yang sesuai dengan peraturan dari perusahaan baik yang tertulis maupun tidak (Nitisemito 2000:199). Kedisiplinan sangat penting bagi suatu organisasi sebab dengan adanya disiplin diharapkan sebagian besar peraturan dapat dijalani oleh karyawan dan pekerjaan dilakukan seefektif mungkin.

3. Kesanggupan bekerja. Menurut Nitisemito (2000:201), kesanggupan tenaga kerja dalam menyelesaikan tugas dan pekerjaan yang telah diserahkan kepadanya dengan sebaikbaiknya dan tepat pada waktunya serta berani menaggung resiko atas tindakan yang diambilnya. Kesanggupan bekerja berarti karyawan mampu melaksanakan tugas dengan baik serta sadar bahwa tugas yang menjadi tanggung jawabnya bukan hanya untuk kepentingan organisasi atau instansi tetapi juga untuk kepentingan sendiri.

4. Kesanggupan melaksanakan perintah. Karyawan yang memiliki kinerja, biasanya bertanggungjawab secara personal dan memiliki kesanggupan melaksanakan perintah. Dalam hal ini, karyawan tersebut tidak suka menunda penyelesaian pekerjaan yang dibebankan oleh atasan kepadanya.

5. Mampu melaksanakan tugas dengan cepat dan benar. Menurut Sutrisno (2009:163), karyawan yang kinerjanya baik, berarti mampu melaksanakan tugas-tugasnya dengan cepat dan benar atau berdaya guna dan berhasil guna. Berdaya guna berarti menyelesaikan tugas-tugasnya tepat waktu; sedangkan berhasil, artinya menyelesaikan tugas-tugas yang dibebankan kepadanya tanpa kesalahan.

\section{E. Pengaruh Kesejahteraan Karyawan Terhadap Semangat Kerja Karyawan}

Salah satu faktor yang mempengaruhi semangat kerja karyawan adalah kesejahteraan karyawan. Menurut Mathis dan Jackson (2002:203), "kesejahteraan karyawan adalah imbalan tidak langsung yang diberikan kepada seseorang karyawan atau sekelompok karyawan sebagai bagian dari keanggotaannya di organisasi".

Pemberian kesejahteraan karyawan bertujuan untuk meningkatkan kesetiaan karyawan, meningkatkan semangat kerja, dan produktivitas kerja karyawan. Keberhasilan suatu organisasi dalam menjalankan aktivitasnya, dipengaruhi oleh semanfat kerja karyawan yang terlibat dalam operasional organisasi tersebut. Semangat kerja dapat merangsang seseorang untuk berkarya dan berkreaktivitas dalam pekerjaannya. Untuk meningkatkan semangat kerja, perusahaan perlu memberikan fasilitas kesejahteraan yang sesuai harapan karyawan. Akan tetapi, jika kesejahteraan yang diberikan perusahaan tidak sesuai yang diharapkan karyawan, maka semangat kerja karyawan menurun. 


\section{METODE PENELITIAN}

\section{A. Populasi dan Sampel}

Populasi pada penelitian ini adalah seluruh karyawan tetap pada PT. Asuransi Jiwasraya (Persero) Medan sebanyak 30 orang. Teknik penentuan sampel adalah sampling sensus, yaitu seluruh anggota populasi sekaligus menjadi sampel penelitian.

\section{B. Operasionalisasi Variabel}

Definisi operasionalisasi variabel yang diteliti adalah:

a. Variabel bebas $(X)$ adalah kesejahteraan karyawan yaitu fasilitas yang diberikan perusahaan kepada karyawan. Indikator pengukurannya adalah pembayaran gaji saat tidak bekerja saat sakit, cuti dan libur, tunjangan keluarga, tunjangan hari raya, kendaraan dinas, pakaian dinas, rekreasi bersama, biaya pengobatan dan perawatan kesehatan. Skala pengukurannya adalah skala likert.

b. Variabel terikat (Y) adalah semangat kerja karyawan, yaitu kesungguhan karyawan dalam menyelesaikan tugas-tugas yang d: prestasi kerja, disiplin, kesanggupan bekerja, kesanggupan melaksanakan perintah, mampu melaksanakan tugas dengan cepat dan benar. Skala pengukurannya adalah skala likert.

\section{Teknik Pengumpulan Data}

Pada penelitian ini digunakan data primer melalui kuesioner dan dokumentasi.

\section{Uji Validitas dan Reliabilitas instrumen}

Pengujian validitas tiap butir menggunakan analisis item dengan rumus:

$$
r_{x y}=\frac{n \sum X_{i} Y_{i}-\left(\sum X_{i}\right)\left(\sum Y_{i}\right)}{\sqrt{\left\{n \sum X_{i}^{2}-\left(\sum X_{i}\right)^{2}\right.}\left\{n \sum Y_{i}^{2}-\left(\sum Y_{i}\right)^{2}\right\}}
$$

Keterangan: $X_{i}=$ Skor tiap butir indikator, $Y_{i}=$ Skor total butir, $n=$ Jumlah sampel

Pengujian reliabilitas instrumen dapat dilakukan dengan teknik belah dua dari Spearmen Brown dengan rumus:

$$
r i=\frac{2 r b}{1+r b}
$$

Keterangan: $r_{i}=$ reliabilitas internal seluruh instrumen

$\mathrm{rb}=$ korelasi product moment antara belahan pertama dan kedua.

Perhitungan reliabilitas pada penelitian ini menggunakan analisis yang dikembangkan oleh Alpha Cronbach. Pada uji ini dinilai reliabel jika lebih besar dari 0,50 di mana kriteria sebagai berikut:

$\propto \geq 0,50$ artinya instrumen reliabel.

$\propto<0,50$ artinya instrumen tidak reliabel.

\section{E. Analisis Regresi Linear Sederhana}

Teknik analisis data yang digunakan adalah regresi linear sederhana yang berguna untuk mengetahui pengaruh kesejahteraan karyawan terhadap semangat kerja karyawan (Supranto 2001:182), dengan rumus:

$\mathrm{Y}=\mathrm{a}+\mathrm{bX}+\varepsilon \mathrm{i}$

Sehingga diperoleh nilai a dengan rumus:

$\mathrm{a}=\bar{Y}-\mathrm{b} \bar{X}$

Nilai $b$ dihitung dengan menggunakan rumus: 
Volume 18 Nomor 2

$$
\mathrm{b}=\frac{n \sum X Y-\sum X \sum Y}{n \sum X^{2}-(X)^{2}}
$$

Keterangan: $X=$ Kesejahteraan karyawan $\quad Y=$ Semangat kerja karyawan

$$
\begin{array}{ll}
\mathrm{a}=\text { Nilai konstanta } & \mathrm{b}=\text { Koefisien regresi } \\
\mathrm{n}=\text { Jumlah sampel } & \varepsilon \mathrm{i}=\text { Error }
\end{array}
$$

Analisis korelasi untuk mengetahui keeratan hubungan antara kesejahteraan karyawan dengan semangat kerja karyawan, dengan rumus:

$$
r_{X Y}=\frac{n \sum X Y-\left(\sum X\right)\left(\sum Y\right)}{\sqrt{\left\{n \sum X^{2}-\left(\sum X\right)^{2}\right\}\left\{n \sum Y^{2}-\left(\sum Y\right)^{2}\right\}}}
$$

Keterangan : $r_{x y}=$ koefisien korelasi

$$
\mathrm{n}=\text { jumlah sampel }
$$

Untuk mengetahui sejauh mana semangat kerja karyawan dapat dijelaskan oleh kesejahteraan karyawan, ditentukan dari koefisien determinasi dengan rumus:

$\mathrm{D}=\mathrm{r}^{2}$

Pembuktian apakah hipotesis diterima atau ditolak menggunakan prosedur pengujian sebagai berikut:

1. $\mathrm{H}_{0}: \beta \mathrm{i}=0$, artinya kesejahteraan karyawan tidak berpengaruh positif terhadap semangat kerja karyawan pada PT. Asuransi Jiwasraya (Persero) Medan.

$\mathrm{H}_{1}: \beta \mathrm{i} \neq 0$, artinya kesejahteraan karyawan berpengaruh positif terhadap semangat kerja karyawan pada PT. Asuransi Jiwasraya (Persero) Medan.

2. Sampel $=n=30$ orang dengan tingkat signifikansi $(\propto) 5 \%$.

F. Statistik uji t (Supranto, 2001,194):

$t=\frac{\beta i}{S_{e \beta}}$

Dimana: $\mathrm{t}=\mathrm{t}_{\text {hitung, }} \beta \mathrm{i}=$ koefisien regresi, $\mathrm{S}_{\mathrm{e} \beta}=$ standar error koefisien regresi

3. Nilai tabel: $\mathrm{t}(\alpha / 2 ; n-2)$

$\mathrm{H}_{0}$ diterima jika $-t(\alpha / 2 ; n-2) \leq t_{\text {hitung }} \leq t(\alpha / 2 ; n-2)$

$\mathrm{H}_{1}$ diterima jika $\mathrm{t}_{\text {hitung }}<-t(\varepsilon / 2 ; n-2) \Delta$ atau $t_{\text {hitung }} \mathrm{S}(\mathrm{t} / 2 ; n-2)$

Pengujian dilakukan dengan menggunakan program SPSS (Statistical Program for Social Sciences) versi 20.0.

Berdasarkan pengolahan data dengan menggunakan program SPSS (Statistical Program for Social Sciences) versi 20,0. Hasil uji secara simultan disajikan pada tabel berikut ini:.

Tabel 1. Case Processing Summary

\begin{tabular}{|ll|r|r|}
\hline & \multicolumn{1}{|c|}{$\mathrm{N}$} & \multicolumn{1}{c|}{$\%$} \\
\hline Cases & Valid & 30 & 100.0 \\
& Excluded (a) & 0 & .0 \\
& Total & 30 & 100.0 \\
\hline
\end{tabular}

a Listwise deletion based on all variables in the procedur

Berdasarkan tabel di atas, diketahui bahwa jawaban 30 responden $100 \%$ sudah valid. Hasil uji reliabilitas secara simultan mengenai kesejahteraan karyawan disajikan sebagai berikut:

Tabel 2. Reliability Statistics

\begin{tabular}{|r|r|}
\hline Cronbach's Alpha & Nof Items \\
\hline 0,871 & 8 \\
\hline
\end{tabular}

Sumber: Hasil pengolahan data SPSS versi 20,0 
Dari tabel di atas, terlihat bahwa kedelapan indikator variabel kesejahteraan karyawan pada PT. Asuransi Jiwasraya (Persero) Medan seluruhnya sudah reliabel, karena Cronbach's Alpha $=0,871>0,50$. Hasil uji validitas dan reliabilitas secara parsial mengenai kesejahteraan karyawan disajikan pada tabel berikut:

Tabel 3. Hasil Uji Validitas dan Reliabilitas

\begin{tabular}{|l|c|c|c|c|}
\hline \multicolumn{1}{|c|}{ Indikator penelitian } & Correlation & Ket & $\begin{array}{c}\text { Cronbach's } \\
\text { Alpha if Item }\end{array}$ & Ket \\
\hline Pembayaran gaji saat tidak bekerja (V1) & 0,699 & Valid & 0,847 & Reliabel \\
Pembayaran gaji saat cuti dan libur (V2) & 0,735 & Valid & 0,847 & Reliabel \\
Tunjangan keluarga (V3) & 0,487 & Valid & 0,870 & Reliabel \\
Tunjangan hari raya (V4) & 0,707 & Valid & 0,846 & Reliabel \\
Kendaraan dinas (V5) & 0,498 & Valid & 0,869 & Reliabel \\
Pakaian dinas (V6) & 0,613 & Valid & 0,856 & Reliabel \\
Rekreasi bersama (V7) & 0,647 & Valid & 0,853 & Reliabel \\
Pengobatan dan perawatan kesehatan & 0,661 & Valid & 0,851 & Reliabel \\
(V8) & & & & \\
\hline
\end{tabular}

Sumber: Hasil pengolahan data SPSS versi 20,0

Berdasarkan Tabel 3. diketahui bahwa seluruh indikator pengukuran variabel kesejahteraan karyawan adalah valid, karena rata-rata nilai $\mathrm{r}$-hitung lebih besar dari $\mathrm{r}$-kritis $(0,30)$. Dari tabel tersebut juga diketahui bahwa seluruh indikator pengukuran variabel sudah reliabel, karena nilai alpha lebih besar 0,50.

Hasil uji validitas secara simultan mengenai semangat kerja karyawan disajikan pada tabel berikut:

Tabel .4.. Case Processing Summary

\begin{tabular}{|ll|r|r|}
\hline & & \multicolumn{1}{|c|}{$\mathbf{~}$} & \multicolumn{1}{c|}{$\mathbf{1}$} \\
\hline Cases & Valid & 30 & 100.0 \\
& Excluded(a) & 0 & .0 \\
& Total & 30 & 100.0 \\
\hline
\end{tabular}

a Listwise deletion based on all variables in the procedure

Sumber: Hasil pengolahan data SPSS versi 20,0

Dari tabel di atas, terlihat bahwa jawaban 30 responden $100 \%$ sudah valid. Hasil uji reliabilitas secara simultan mengenai semangat kerja karyawan disajikan sebagai berikut :

Tabel .5. Reliability Statistics

\begin{tabular}{|r|r|}
\hline Cronbach's Alpha & N of Items \\
\hline 0,800 & 6 \\
\hline
\end{tabular}

Sumber: Hasil pengolahan data SPSS versi 20,0

Dari tabel di atas, terlihat bahwa keenam indikator variabel semangat kerja karyawan pada PT. Asuransi Jiwasraya (Persero) Medan seluruhnya sudah reliabel, karena Cronbach's Alpha $=0,800>0,50$. Hasil uji validitas dan reliabilitas secara parsial mengenai semangat kerja karyawan disajikan pada tabel berikut:

Tabel 6. Hasil Uji Validitas dan Reliabilitas

\begin{tabular}{|c|c|c|c|c|}
\hline Indikator penelitian & Correlation & Ket & $\begin{array}{c}\text { Cronbach's } \\
\text { Alpha if Item }\end{array}$ & Ket \\
\hline Banyaknya pekerjaan yang diselesaikan & 0,760 & Valid & 0,714 & Reliabel \\
\hline
\end{tabular}




\begin{tabular}{|l|c|c|c|c|}
\hline \multicolumn{1}{|c|}{ Indikator penelitian } & Correlation & Ket & $\begin{array}{c}\text { Cronbach's } \\
\text { Alpha if Item }\end{array}$ & Ket \\
\hline (V1) & 0,484 & Valid & 0,785 & Reliabel \\
Disiplin kerja karyawan (V2) & 0,517 & Valid & 0,779 & Reliabel \\
Tindakan disiplin kerja (V3) & 0,578 & Valid & 0,764 & Reliabel \\
Kesanggupan menyelesaikan pekerjaan & 0,573 & Valid & 0,766 & Reliabel \\
(V4) & 0,444 & Valid & 0,794 & Reliabel \\
Perintah kerja (V5) & & & \\
Bekerja dengan cepat dan tepat (V6) &
\end{tabular}

Sumber: Hasil pengolahan data SPSS versi 20,0

Dari Tabel 6, diketahui bahwa seluruh indikator pengukuran variabel semangat kerja karyawan adalah valid, karena rata-rata nilai $\mathrm{r}_{\text {-hitung }}$ lebih besar dari $\mathrm{r}_{\text {-kritis }}(0,30)$. Dari tabel tersebut juga diketahui bahwa seluruh indikator pengukuran variabel sudah reliabel, karena nilai alpha lebih besar 0,50 .

\section{HASIL DAN PEMBAHASAN}

\section{A. Pengujian Hipotesis}

Teknik analisis data yang digunakan adalah regresi linear sederhana yang berguna untuk mengetahui pengaruh kesejahteraan karyawan terhadap semangat kerja karyawan. Pengolahan data dilakukan dengan menggunakan program SPSS (Statistical Program for Social Sciences) versi 20,0.

Nilai koefisien korelasi (R) berguna untuk mengetahui pengaruh kesejahteraan karyawan dengan semangat kerja karyawan. Nilai koefisien determinan ( $\mathrm{R}$ Square) menunjukkan sejauhmana variabel terikat, yaitu semangat kerja karyawan dapat dijelaskan oleh variabel bebas, yaitu kesejahteraan karyawan. Berdasarkan print output SPSS versi 20,0 diperoleh hasil analisis sebagai berikut:

Tabel 7. Model Summary

\begin{tabular}{|l|c|r|r|r|}
\hline Model & \multicolumn{1}{|c|}{$\boldsymbol{R}$} & $\boldsymbol{R}$ Square & Adjusted R Square & Std. Error of the Estimate \\
\hline 1 & $0,826(\mathrm{a})$ & 0,683 & 0,672 & 0,36609 \\
\hline
\end{tabular}

a Predictors: (Constant), $\mathrm{X}$

Sumber: Hasil pengolahan data SPSS versi 20,0

Dari tabel di atas, diketahui nilai koefisien korelasi (R) sebesar 0,826, artinya kesejahteraan karyawan mempunyai hubungan yang kuat dengan semangat kerja karyawan pada PT. Asuransi Jiwasraya (Persero) Medan. Nilai koefisien determinan ( $R$ Square) sebesar 0,683, artinya semangat kerja karyawan dapat dijelaskan oleh kesejahteraan karyawan sebesar $68,3 \%$ sedangkan $31,7 \%$ lagi dijelaskan oleh faktor lain seperti promosi jabatan dan pemberian insentif.

Untuk membuktikan hipotesis digunakan uji $t$, dengan hasil pengujian sebagai berikut:

Tabel 8. Coefficients(a)

\begin{tabular}{|l|c|r|r|r|c|}
\hline \multirow{2}{*}{} & \multicolumn{2}{|c|}{ Unstandardized Coefficients } & Standardized Coefficients & \multirow{2}{*}{$\boldsymbol{t}$} & \multirow{2}{*}{ Sig. } \\
\cline { 2 - 7 } & $\boldsymbol{B}$ & Std. Error & Beta & & 0,022 \\
\hline (Constant) & 0,773 & 0,295 & & 014 \\
X1 & 0,696 & 0,090 & 0,826 & 7,767 & 0,000 \\
\hline
\end{tabular}

a Dependent Variable: Y

Sumber: Hasil pengolahan data SPSS versi 20,0 
Berdasarkan tabel 8, diperoleh persamaan regresi linear sederhana adalah $Y=0,773+0,696$ X. Artinya, kesejahteraan karyawan berpengaruh positif terhadap semangat kerja karyawan pada PT. Asuransi Jiwasraya (Persero) Medan. Hal ini dapat dilihat dari nilai koefisien regresinya yang bertanda positif. Angka 0,773 menunjukkan pengaruh faktor lain terhadap semangat kerja karyawan.

Dari tabel 8, diketahui nilai $t_{\text {hitung }}$ sebesar 7,767 dengan tingkat signifikansi sebesar 0,000, sehingga $\mathrm{H}_{1}$ diterima dan $\mathrm{H}_{0}$ ditolak. Artinya, kesejahteraan karyawan berpengaruh signifikan terhadap semangat kerja karyawan pada PT. Asuransi Jiwasraya (Persero) Medan, dapat diterima pada tingkat signifikansi 5 persen.

\section{B. Analisis Kuesioner Mengenai Kesejahteraan Karyawan}

Berdasarkan kuesioner jawaban responden dapat dihitung jumlah dan persentase jawaban responden yang memilih tiap alternatif jawaban mengenai kesejahteraan karyawan, seperti disajikan pada Tabel 9.

Tabel 9. Jumlah dan Persentase Jawaban Responden Mengenai Kesejahteraan Karyawan Pada PT. Asuransi Jiwasraya (Persero) Medan.

\begin{tabular}{|c|c|c|c|c|c|c|c|c|c|c|}
\hline \multirow{2}{*}{ Indikator pengukuran variabel } & \multicolumn{10}{|c|}{ Alternatif Jawaban } \\
\hline & \multicolumn{2}{|r|}{ SS } & \multicolumn{2}{|r|}{ S } & \multicolumn{2}{|c|}{$\mathrm{CS}$} & \multicolumn{2}{|c|}{ TS } & \multicolumn{2}{|c|}{ STS } \\
\hline $\begin{array}{l}\text { Pembayaran gaji saat tidak } \\
\text { bekerja }\end{array}$ & 3 & $10 \%$ & 15 & $50 \%$ & 7 & $23 \%$ & 3 & $10 \%$ & 2 & $7 \%$ \\
\hline $\begin{array}{l}\text { Pembayaran gaji saat cuti dan } \\
\text { libur }\end{array}$ & 1 & $3 \%$ & 14 & $47 \%$ & 11 & $37 \%$ & 3 & $10 \%$ & 1 & $3 \%$ \\
\hline Tunjangan keluarga & 2 & $7 \%$ & 6 & $20 \%$ & 5 & $17 \%$ & 16 & $53 \%$ & 1 & $3 \%$ \\
\hline Tunjangan hari raya & 4 & $13 \%$ & 12 & $40 \%$ & 5 & $17 \%$ & 7 & $23 \%$ & 2 & $7 \%$ \\
\hline Kendaraan dinas & 2 & $7 \%$ & 7 & $23 \%$ & 5 & $17 \%$ & 15 & $50 \%$ & 1 & $3 \%$ \\
\hline Pakaian dinas & 3 & $10 \%$ & 15 & $50 \%$ & 6 & $20 \%$ & 5 & $17 \%$ & 1 & $3 \%$ \\
\hline Rekreasi bersama & 3 & $10 \%$ & 11 & $37 \%$ & 9 & $30 \%$ & 4 & $13 \%$ & 3 & $10 \%$ \\
\hline $\begin{array}{l}\text { Pengobatan dan perawatan } \\
\text { kesehatan }\end{array}$ & 4 & $13 \%$ & 7 & $23 \%$ & 13 & $43 \%$ & 5 & $17 \%$ & 1 & $3 \%$ \\
\hline
\end{tabular}

Sumber: Hasil pengolahan data SPSS versi 20,0

Dari 30 responden yang menyatakan bahwa pembayaran gaji saat tidak bekerja sangat sesuai yang diharapkan sebanyak 3 orang $(10 \%)$, sesuai 15 orang $(50 \%)$, cukup sesuai 7 orang $(23 \%)$, tidak sesuai 3 orang $(10 \%)$ dan responden yang menyatakan sangat tidak sesuai 2 orang (7\%). Dari jumlah dan persentase tersebut, berarti pembayaran gaji saat tidak bekerja sudah sesuai yang diharapkan.

Responden yang menyatakan bahwa pembayaran gaji saat cuti dan libur sangat sesuai yang diharapkan sebanyak 1 orang (3\%), sesuai 14 orang $(47 \%)$, cukup sesuai 11 orang (37\%), tidak sesuai 3 orang (10\%) dan responden yang menyatakan sangat tidak sesuai 1 orang (3\%). Dari jumlah dan persentase tersebut, berarti pembayaran gaji saat cuti dan libur sudah sesuai yang diharapkan.

Responden yang menyatakan bahwa pemberian tunjangan keluarga sangat sesuai yang diharapkan sebanyak 2 orang (7\%), sesuai 6 orang (20\%), cukup sesuai 5 orang (17\%), tidak sesuai 16 orang (53\%) dan responden yang menyatakan sangat tidak sesuai 1 orang (3\%). Dari jumlah dan persentase tersebut, berarti besar tunjangan keluarga belum sesuai yang diharapkan karyawan, karena perusahaan hanya memberikan sebesar 15\% dari gaji pokok. Untuk itu, maka seharusnya perusahaan menambah persentase tunjangan keluarga untuk meningkatkan kesejahteraan karyawan. 
Responden yang menyatakan bahwa pemberian tunjangan hari raya sangat sesuai yang diharapkan sebanyak 4 orang (13\%), sesuai 12 orang (40\%), cukup sesuai 5 orang (17\%), tidak sesuai 7 orang $(23 \%)$ dan responden yang menyatakan sangat tidak sesuai 2 orang $(7 \%)$. Dari jumlah dan persentase tersebut, berarti pemberian tunjangan hari raya sudah sesuai yang diharapkan karyawan.

Responden yang menyatakan bahwa pemberian kendaraan dinas sangat sesuai yang diharapkan sebanyak 2 orang (7\%), sesuai 7 orang (23\%), cukup sesuai 5 orang (17\%), tidak sesuai 15 orang (50\%) dan responden yang menyatakan sangat tidak sesuai 1 orang (3\%). Dari jumlah dan persentase tersebut, berarti pemberian kendaraan dinas belum sesuai yang diharapkan karena hanya diberikan kepada branch manager dan kepala seksi.

Responden yang menyatakan bahwa pembagian pakaian dinas secara gratis kepada karyawan sangat sesuai yang diharapkan sebanyak 3 orang $(10 \%)$, sesuai 15 orang (50\%), cukup sesuai 6 orang (20\%), tidak sesuai 5 orang $(17 \%)$ dan responden yang menyatakan sangat tidak sesuai 1 orang (3\%). Dari jumlah dan persentase tersebut, berarti pembagian pakaian dinas secara gratis sudah sesuai yang diharapkan karyawan.

Responden yang menyatakan bahwa pelaksanaan rekreasi bersama sangat sesuai yang diharapkan sebanyak 3 orang (10\%), sesuai 11 orang (37\%), cukup sesuai 9 orang (30\%), tidak sesuai 4 orang $(13 \%)$ dan responden yang menyatakan sangat tidak sesuai 3 orang $(10 \%)$. Dari jumlah dan persentase tersebut, berarti pelaksanaan rekreasi bersama sudah sesuai yang diharapkan karyawan.

Responden yang menyatakan bahwa pemberian biaya pengobatan dan pengobatan kepada karyawan yang sakit sangat sesuai yang diharapkan sebanyak 4 orang (13\%), sesuai 7 orang $(23 \%)$, cukup sesuai 13 orang $(43 \%)$, tidak sesuai 5 orang $(17 \%)$ dan responden yang menyatakan sangat tidak sesuai 1 orang (3\%). Dari jumlah dan persentase tersebut, berarti biaya pengobatan dan pengobatan kepada karyawan yang sakit sudah sesuai yang diharapkan.

\section{Analisis Kuesioner Mengenai Semangat Kerja Karyawan}

Berdasarkan kuesioner jawaban responden, dapat dihitung jumlah dan persentase jawaban responden yang memilih tiap alternatif jawaban mengenai semangat kerja karyawan, seperti disajikan pada Tabel 10.

Tabel 10. Jumlah dan Persentase Jawaban Responden Mengenai Semangat Kerja Karyawan Pada PT. Asuransi Jiwasraya (Persero) Medan

\begin{tabular}{|c|c|c|c|c|c|c|c|c|c|c|}
\hline \multirow{3}{*}{$\begin{array}{l}\text { Indikator pengukuran variabel } \\
\text { Pekerjaan yang diselesaikan }\end{array}$} & \multicolumn{10}{|c|}{ Alternatif Jawaban } \\
\hline & \multicolumn{2}{|c|}{ SS } & \multicolumn{2}{|c|}{$S$} & \multicolumn{2}{|c|}{ CS } & \multicolumn{2}{|c|}{ TS } & \multicolumn{2}{|c|}{ STS } \\
\hline & 2 & $7 \%$ & 11 & $37 \%$ & 8 & $27 \%$ & 6 & $20 \%$ & 3 & $10 \%$ \\
\hline Disiplin kerja karyawan & 1 & 3 & 5 & 3 & 14 & & & 0 & & $\%$ \\
\hline Tind & 1 & $3 \%$ & 9 & $30 \%$ & 12 & $40 \%$ & 6 & $20 \%$ & & $7 \%$ \\
\hline $\begin{array}{l}\text { Kesanggupan } \\
\text { tugas }\end{array}$ & 0 & $0 \%$ & 8 & $27 \%$ & 8 & $27 \%$ & 13 & $43 \%$ & 1 & $3 \%$ \\
\hline Perintah kerja & 1 & $3 \%$ & 8 & $27 \%$ & 12 & $40 \%$ & 8 & $27 \%$ & 1 & $3 \%$ \\
\hline Bekerja dengan cepat dan tepat & 0 & $0 \%$ & 5 & $17 \%$ & 20 & $67 \%$ & 4 & $13 \%$ & 1 & $3 \%$ \\
\hline
\end{tabular}

Sumber: Hasil pengolahan data SPSS versi 20,0

Dari 30 responden yang menyatakan bahwa pelaksanaan penilaian prestasi kerja karyawan sangat sesuai sebanyak 2 orang $(7 \%)$, sesuai 11 orang $(37 \%)$, cukup sesuai 8 orang $(27 \%)$, tidak sesuai 6 orang $(20 \%)$ dan responden yang menyatakan sangat tidak sesuai 3 orang $(10 \%)$. Dari jumlah dan persentase tersebut, berarti penilaian prestasi kerja karyawan sudah sesuai yang diharapkan. 
Responden yang menyatakan bahwa disiplin kerja karyawan sangat baik sebanyak 1 orang (3\%), baik 9 orang (30\%), cukup baik 14 orang $(47 \%)$, dan responden yang menyatakan tidak baik 6 orang $(20 \%)$. Dari jumlah dan persentase tersebut, berarti karyawan memiliki disiplin kerja yang baik.

Responden yang menyatakan bahwa tindakan disiplin kerja yang diberlakukan oleh atasan dilaksanakan dengan adil tanpa terkecuali telah terlaksana sangat baik sebanyak 2 orang (7\%), sesuai 11 orang (37\%), cukup sesuai 12 orang (40\%), tidak sesuai 6 orang (20\%) dan responden yang menyatakan sangat tidak sesuai 2 orang (7\%). Dari jumlah dan persentase tersebut, berarti tindakan disiplin kerja yang diberlakukan oleh atasan dilaksanakan dengan adil tanpa terkecuali.

Responden yang menyatakan bahwa pekerjaan yang dibebankan atasan sanggup diselesaikan sesuai yang diharapkan sebanyak 8 orang (27\%), cukup sesuaik 8 orang (27\%), tidak sesuai 13 orang (43\%) dan responden yang menyatakan sangat tidak sesuai 1 orang (3\%). Dari jumlah dan persentase tersebut, berarti pekerjaan yang dibebankan atasan sanggup diselesaikan dengan baik.

Responden yang menyatakan bahwa perintah kerja yang diberikan oleh atasan dapat dilaksanakan sangat baik sebanyak 1 orang (3\%), baik 8 orang $(27 \%)$, tidak baik 12 orang $(40 \%)$ dan responden yang menyatakan sangat tidak baik 1 orang (3\%). Dari jumlah dan persentase tersebut, berarti perintah kerja yang diberikan oleh atasan dapat dilaksanakan dengan baik.

Responden yang menyatakan bahwa karyawan mampu menyelesaikan tugas yang dibebankan atasan dengan cepat dan benar 5 orang (17\%), baik 20 orang (67\%), tidak baik 4 orang (13\%) dan responden yang menyatakan sangat tidak baik 1 orang (3\%). Dari jumlah dan persentase tersebut, berarti karyawan mampu menyelesaikan tugas yang dibebankan atasan dengan cepat dan benar.

\section{Analisis Pengaruh Kesejahteraan Terhadap Semangat Kerja Karyawan}

Dilihat dari nilai koefisien regresinya, diketahui bahwa pengaruh kesejahteraan karyawan terhadap semangat kerja karyawan sebesar 0,696, artinya setiap perubahan kesejahteraan karyawan, maka semangat kerja karyawan akan meningkat sebesar 0,696. Dengan demikian, terdapat pengaruh positif antara kesejahteraan karyawan dengan semangat kerja karyawan. Hal ini terbukti dari hasil uji $t$, yang menunjukkan bahwa kesejahteraan karyawan berpengaruh signifikan terhadap semangat kerja karyawan pada PT. Asuransi Jiwasraya (Persero) Medan, dapat diterima pada tingkat signifikansi 5 persen.

\section{KESIMPULAN}

Berdasarkan analisis data dan setelah membahas hasil penelitian maka penulis mengambil kesimpulan sebagai berikut:

1. Persamaan regresi linear sederhana yang diperoleh adalah $Y=0,773+0,696 X$. Artinya, kesejahteraan karyawan berpengaruh positif terhadap semangat kerja karyawan pada PT. Asuransi Jiwasraya (Persero) Medan. Hal ini dapat dilihat dari nilai koefisien regresinya yang bertanda positif.

2. Nilai $t_{\text {hitung }}$ sebesar 7,767 dengan tingkat signifikansi sebesar 0,000 , sehingga $\mathrm{H}_{1}$ diterima dan $\mathrm{H}_{0}$ ditolak. Artinya, kesejahteraan karyawan berpengaruh signifikan terhadap semangat kerja karyawan pada PT. Asuransi Jiwasraya (Persero) Medan, dapat diterima pada tingkat signifikansi 5 persen.

3. Nilai koefisien korelasi (R) sebesar 0,826, artinya kesejahteraan karyawan mempunyai hubungan yang kuat dengan semangat kerja karyawan pada PT. Asuransi Jiwasraya (Persero) Medan. Nilai koefisien determinan ( $R$ Square) sebesar 0,683, artinya semangat kerja karyawan dapat dijelaskan oleh kesejahteraan karyawan sebesar $68,3 \%$ sedangkan $31,7 \%$ lagi dijelaskan oleh faktor lain seperti promosi jabatan dan pemberian insentif. 


\section{DAFTAR PUSTAKA}

Anoraga, Pandji. 2000. Manajemen Bisnis. Cetakan Kedua, Jakarta: Rineka Cipta

Bagasworo, Wasi, 2007. Pengaruh pelaksanaan program pelayanan kesejahteraan karyawan terhadap semangat kerja karyawan pada PT. Arcoma Timur Jakarta, Karya Ilmiah, Universitas Gunadarma.

Handoko, T. Hani, 2004. Manajemen Personalia dan Sumber Daya Manusia, Edisi Kedua, Yogyakarta: BPFE-UGM.

Hariandja, Marihot Tua Effendi, 2002. Manajemen Sumber Daya Manusia, Jakarta: PT. Gramedia Widiasarana Indonesia.

Hasibuan, Malayu, 2003. Manajemen Sumber Daya Manusia, Cetakan Keenam, Jakarta: Bumi Aksara.

Mathis, Robert L dan Jackson, John H., 2002. Manajemen Sumber Daya Manusia, Buku Dua, Alih Bahasa: Jimmy Sadeli dan Bayu Prawira Hie, Jakarta: Salemba Empat.

Nasution, Siska Malisa, 2009. Pengaruh Kesejahteraan Karyawan Terhadap Semangat Kerja Karyawan pada PT. Pangansari Utama Medan, Skripsi: Medan: USU.

Nitisemito, Alex S. 2002. Manajemen Personalia. Edisi Kelima, Cetakan Kedua, Yogyakarta : BPFE.

Robbins, Stephen P., dan Jugde, Timothy A., 2008. Perilaku Organisasi, Buku Satu, Edisi Keduabelas, Jakarta: Salemba Empat.

Saydam, Gouzali, 2005. Manajemen Sumber Daya Manusia: Suatu Pendekatan Makro, Cetakan Ketiga, Jakarta: Djambatan.

Sofyandi, Herman, 2008. Manajemen Sumber Daya Manusia, Edisi Pertama, Cetakan Pertama, Yogyakarta: Graha Ilmu.

Supranto, J., 2001. Statistik: Teori dan Aplikasi, Jilid Satu, Edisi Keenam, Cetakan Pertama, Jakarta: Erlangga.

Sutrisno, Edy, 2009. Manajemen Sumber Daya Manusia, Edisi Pertama, Cetakan Pertama, Jakarta: Prenada Media Group.

Sugiyono, 2009. Metode Penelitian, Edisi Keduabelas, Bandung : CV. Alfabeta. 